\title{
FRACTURE BEHAVIOR AND FAILURE ANALYSIS OF SELF COMPACTED CONCRETE DEEP BEAMS REINFORCED BY CFRP BARS
}

\author{
KH. HEIZA \\ Professor of RC Structures Civil Engineering Department, \\ Vice Dean, Faculty of Engineering, Menofia University, Egypt. \\ e-mail: khheiza@yahoo.com
}

Key words: Self compacted concrete, Deep beams, Shear strength, CFRP bars, Opening.

\begin{abstract}
The behavior of deep beams is significantly different from shallow beams, the reinforced concrete plane section does not remain plane after deformation. The utilization of fiber reinforced polymer, (FRP) and self-compacted concrete in the construction fields has received a special attention world wide during the last decade. An experimental program was carried out to investigate the fracture behavior and failure analysis of self compacted concrete deep beams reinforced by CFRP or steel bars. The experimental program consists of five self-compacting reinforced concrete deep beam models that have a constant cross section of $100 \mathrm{~mm} \times 500 \mathrm{~mm}$ and of a total length $1200 \mathrm{~mm}$. These models were classified into two groups. The first group contains two control beams without opening. The second group contains three beams with opening. The cracking, failure loads, deflections and rotations at different loading stages as well as the crack patterns and modes of failure for the tested beams were observed, recorded and discussed. The results showed that the flexural cracks in deep beams are not critical except in the case where tensile reinforcement ratio is less than the minimum suggested by the codes.
\end{abstract}

\section{Introduction}

Reinforced concrete (RC) deep beams were often used and encountered in many structural applications such as diaphragms, bridges, water tanks, precast and prestressed construction, foundations, silos, bunkers, offshore structures and tall buildings. Deep beams are widely used as transfer girders in offshore structures and foundations. With the strong growth of construction in many developing countries, deep beams at its behavior predication are a subject of considerable attention [1-2]. Current studies indicate that the use of advanced composites materials for structural application is expected to increase exponentially in the next decade. FRP composites can be manufactured in many shapes and forms. Applications of FRP composites in civil, infrastructure engineering are diverse and may include internal reinforcement, structural elements, and externally bonded reinforcement. For concrete reinforcement, the most popular forms of FRP are smooth and deformed bars, prestressing tendons, and pre-cured and cured in place laminates shells. FRP bars and tendons are currently produced with sizes and deformation patterns similar to those of steel bars and strands. FRP composites are light in weight, which means they are easier to transport and install. They are corrosion resistant and therefore perform well in terms of long term durability and maintenance cost. FRP pre-cured and cured in place laminates shells and sheets are used for external concrete reinforcement and FRP shells have been used as jackets for columns [3-5]. The literature is available on RC deep beams behavior for traditional, high strength, and fiber concrete [6-7]. In this research, five self compacted reinforced 
concrete deep beams (two control beams without opening and three beams with opening) were casted cured and tested. The variables examined in the shear tests were the type of reinforcement (CFRP or steel bars) and presence of central opening in the $\mathrm{RC}$ beams. Performance of the tested RC deep beams and modes of failure are presented, compared and discussed.

\section{EXPERIMENTAL TEST PROGRAM}

\section{Self Compacted Reinforced Concrete deep beam details}

An experimental program was carried out to investigate the fracture behavior and modes of failure of self-compacting reinforced concrete deep beams reinforced by using CFRP or steel bars. The experimental program consists of five reinforced concrete deep beam models that have constant cross section with dimensions of $100 \mathrm{~mm}$ width, $500 \mathrm{~mm}$ height, and a total length of $1200 \mathrm{~mm}$. Effective span is $1000 \mathrm{~mm}$. two beams without opening was considered a reference beams without opening (BC1) reinforced with $2 \Phi 12$ CFRP bars and (BC2) reinforced with $4 \Phi 16$ steel bars. Three deep beams were cast with central openings with constant dimension 200x200 mm BOC1 4Ф16 steel, BOC2 2Ф12 CFRP bars and BOC3 4Ф12 CFRP bars. Steel or CFRP bars was used as a main flexural reinforcement, top reinforcement $2 \Phi 10 \mathrm{~mm}$ as a stirrup hangers, $4 \varnothing 6$ as side reinforcement and stirrup $6 \mathrm{~mm}$ in diameter of mild steel @15 cm of the beam span as shown in Figures (1 through 5) which show the typical dimension and details of reinforcement for each mentioned RC deep beam respectively. Table 1 and 2 show the physical and mechanical properties of steel and CFRP bars used as a main flexural reinforcement in self compacted deep beams.

Table (1) Mechanical properties of Steel reinforcements

\begin{tabular}{|c|c|c|c|c|}
\hline Steel Type & $\begin{array}{c}\text { Yield } \\
\text { Stress } \\
\left(\mathrm{kg} / \mathrm{cm}^{2}\right)\end{array}$ & $\begin{array}{c}\text { Tensile } \\
\text { Strength } \\
\left(\mathrm{kg} / \mathrm{cm}^{2}\right)\end{array}$ & $\begin{array}{c}\text { Elongation } \\
\%\end{array}$ & $\begin{array}{c}\text { Modulus } \\
\text { of } \\
\text { Elasticity } \\
\left(\mathrm{t} / \mathrm{cm}^{2}\right)\end{array}$ \\
\hline $\begin{array}{c}\text { High Tensile } \\
\text { bars }\end{array}$ & 3600 & 5200 & 12 & 2100 \\
\hline Mild steel bars & 2400 & 3500 & 20 & 2050 \\
\hline
\end{tabular}

Table (2) Mechanical properties of CFRP bars [8].

\begin{tabular}{|c|c|c|c|c|c|}
\hline $\begin{array}{c}\text { Tensile } \\
\text { strength, } \\
\mathrm{MPa}\end{array}$ & $\begin{array}{c}\text { Tensile } \\
\text { modulus } \\
\text { of } \\
\text { elasticity, } \\
\mathrm{GPa}\end{array}$ & $\begin{array}{c}\text { Ultimate } \\
\text { deformation }\end{array}$ & $\begin{array}{c}\text { Nominal } \\
\text { diameter, } \\
\mathrm{mm}\end{array}$ & $\begin{array}{c}\text { Nominal } \\
\text { area, } \\
\mathrm{mm}^{2}\end{array}$ & $\begin{array}{c}\text { Ultimate } \\
\text { load, } \\
\mathrm{KN}\end{array}$ \\
\hline 2300 & 130 & $1.8 \%$ & 12 & 113 & 2600 \\
\hline
\end{tabular}

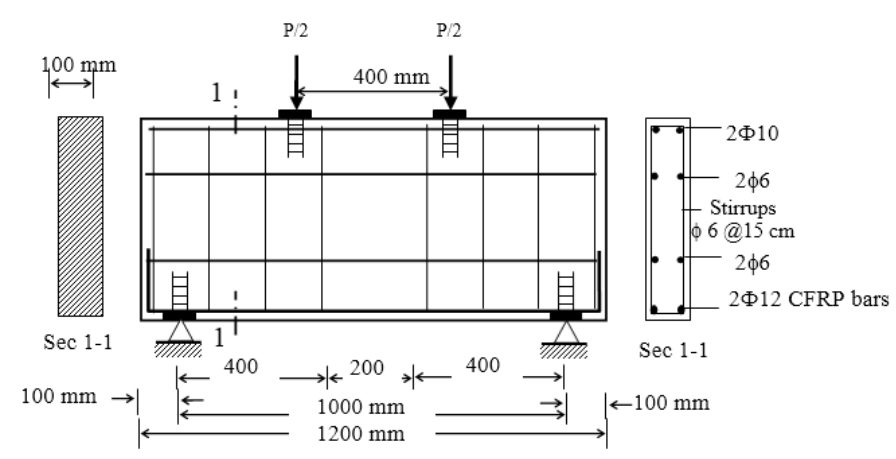

Fig. 1. Typical dimensions and details of reinforcement of the beam $\mathrm{BC} 1$

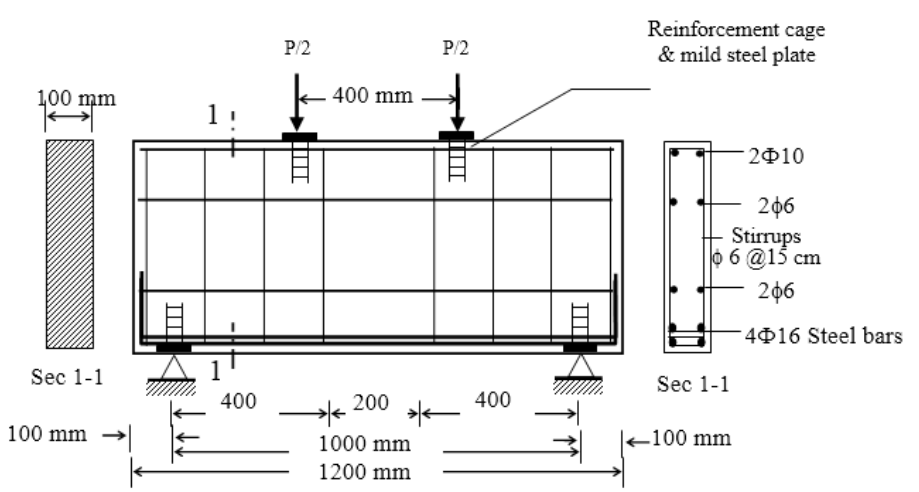

Fig. 2. Typical dimensions and details of reinforcement of the beam $\mathrm{BC} 2$

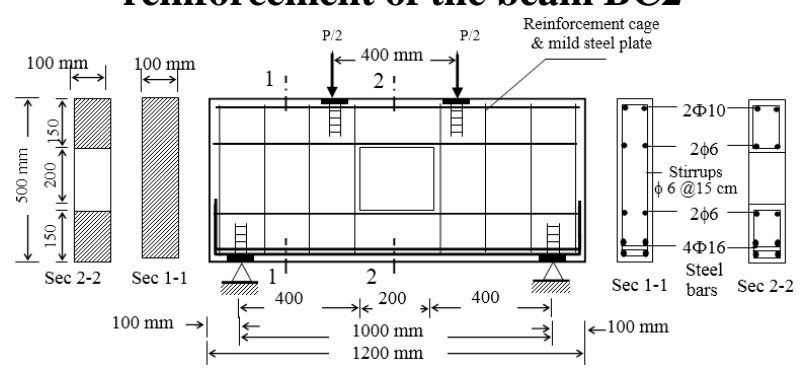

Fig. 3. Typical dimensions and details of reinforcement of the beam BOC1 


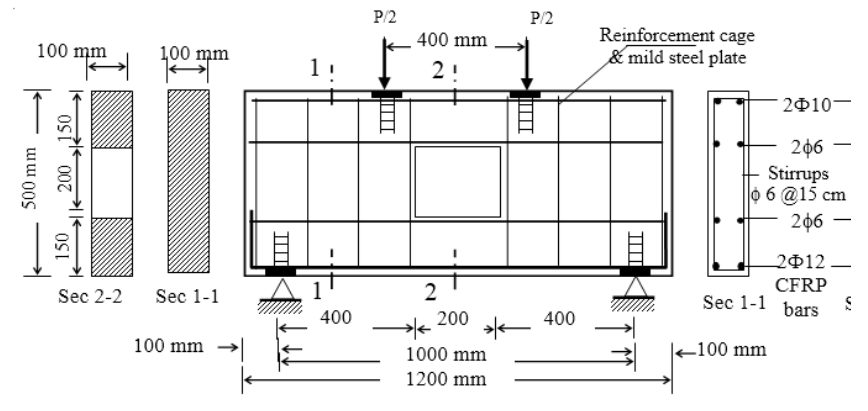

Fig. 4. Typical dimensions and details of reinforcement of the beam $\mathrm{BOC} 2$

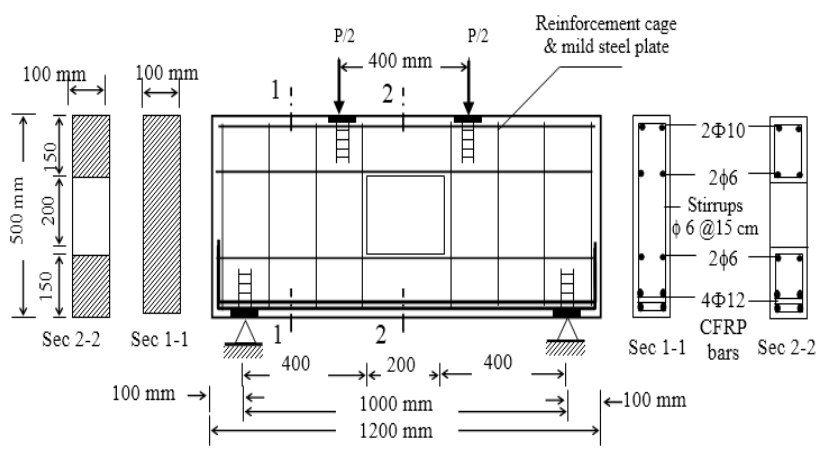

Fig. 5. Typical dimensions and details of reinforcement of the beam $\mathrm{BOC3}$

\section{Material Properties for Self-Compacting Concrete beams}

The properties of the materials such as cement, aggregates, additives and reinforcing steel used for preparing self-compacting concrete beams tested in this study were as follows:

Ordinary Portland cement complied with E.S.S. 373/71 requirements is used for producing SCC. Light gray silica fume, which is a product resulting from the industry of ferro silicon alloys, is used in SCC mixture. The product is a rich silicon dioxide powder where the average size is around 0.1 micrometers with a specific gravity of 2.1. Also, gray fly ash from ash resource with a specific gravity of 2.3 is used in SCC mixture. A continuously graded crushed limestone aggregate with nominal size of 14 $\mathrm{mm}$ and well graded siliceous sand are employed. Their particle-size distributions are within the CSA A23.1 Standards recommendations. The coarse aggregate and sand have fineness modulus of 6.3 and 2.6, respectively. Their bulk specific gravities are 2.7 and 2.68, and their water absorption rates are $0.36 \%$ and $0.59 \%$, respectively. Turbid liquid Sika ViscoCrete (5-400), which is a $4^{\text {th }}$ generation superplasticizer, is used in SCC mixture. It meets the requirements for super plasticizer according to SIA-162. It has an approximate specific gravity of 1.11. CFRP bars, $12 \mathrm{~mm}$ with tensile strength of $2300 \mathrm{MPa}$, is used as bottom (main) reinforcement of three beams BC1 (2Ф12 CFRP), BOC2 (2Ф12 CFRP) and BOC3 (4Ф12 CFRP). $16 \mathrm{~mm}$ diameter of high strength steel bars with tensile strength of $520 \mathrm{MPa}$ was used as bottom reinforcement of two beams BC2 (4Ф16 steel) and BOC1 (4Ф16 steel). $6 \mathrm{~mm}$ diameter of mild steel bars with tensile strength of $350 \mathrm{MPa}$ was used as stirrups and $10 \mathrm{~mm}$ diameter of high strength steel bars with tensile strength of 520 $\mathrm{MPa}$ was used as top reinforcement (stirrups hunger) of all self compacted reinforced concrete deep beams.

\section{Specimen preparation}

Three standard cubes measuring $150 \mathrm{~mm}^{3}$ and three standard cylinders measuring $100 \mathrm{~mm}$ in diameter and $200 \mathrm{~mm}$ in height as well as three standard beams measuring $100 \mathrm{~mm}$ in width and depth and $500 \mathrm{~mm}$ in length are cast for SCC concrete to determine compressive, tensile and flexure strength. All the tested beams are divided into two main groups. First group contains two (BC1 and BC2) reinforced deep beams without opening. Second group contains three (BOC1, BOC2, BOC3) deep beams with opening $200 \times 200 \mathrm{~mm}$. The beams in first and second group are cast using SCC. The stirrups hunger of all beams consists of two high tensile steel bars measuring $10 \mathrm{~mm}$. in diameter and $1200 \mathrm{~mm}$ in length. Each beam contains six stirrups fabricated using mild steel bars with diameter of $6 \mathrm{~mm}$ and located with equal interval, as shown in Figures (1 through 5). All specimens and the tested beams are demolded on the second day of casting and stored in moist curing room for 28 days until the testing day. The mix proportions of materials used for casting the self compacted concrete (SCC) in this study are summarized in Table 3. 
Table 3- mix proportions of materials used for casting the self compacting concrete mix in $\mathrm{kg} / \mathrm{cubic}$ meter

\begin{tabular}{|c|c|c|c|c|c|c|c|c|}
\hline $\begin{array}{c}\text { Mix } \\
\text { Proportion }\end{array}$ & C & W & F.A & C.A & S.F. & f.A. & VEA & $\begin{array}{c}\text { fcu } \\
\text { after 28 } \\
\text { days } \\
\mathrm{kg} / \mathrm{cm} 2\end{array}$ \\
\cline { 2 - 8 } & 400 & 120 & 900 & 900 & 60 & 40 & 10 & 400 \\
\hline
\end{tabular}

Where

$\mathrm{C}=$ Cement, $\mathrm{W}=$ Water, F.A. = Fine aggregate (sand), C.A. = Coarse aggregate (crushed dolomite),

S.F. $=$ Silica fume,$f$.A. $=($ fly ash $), \quad$ VEA $=$ Viscosity enhancing agent.

\section{Test Set-up and Instrumentation}

Reinforced concrete deep beams were tested under two concentrated loads up to failure. A steel frame of $2000 \mathrm{KN}$ capacity was used for testing beams in Menoufiya RC lab. facility. Loads were applied in increments using a hydraulic jack of $1000 \mathrm{KN}$ maximum capacity as shown in Fig.6. Two dial gauges of $0.01 \mathrm{~mm}$ accuracy and a total capacity of $25 \mathrm{~mm}$ were fixed to measure the deflection at mid-span, and under the concentrated load. One dial gauges of a total capacity of $25 \mathrm{~mm}$ was fixed at the end support to measure the rotation at the support as shown in Fig. 6. Demec points were arranged and fixed on the painted side of each tested beam near top and bottom surfaces of the RC beam in four rows at the center of $\mathrm{RC}$ beam span to measure strains in tension and compression. Concrete strains were measured using digital strain gauges of $200 \mathrm{~mm}$ gauge length and $0.001 \mathrm{~mm}$ accuracy. A magnifying lens was used to observe the crack propagation clearly. Cracks were traced numbered and marked at each load increment. Figure 6 shows the arrangement of dial gauges and demec points for all reinforced concrete deep beams during testing process.

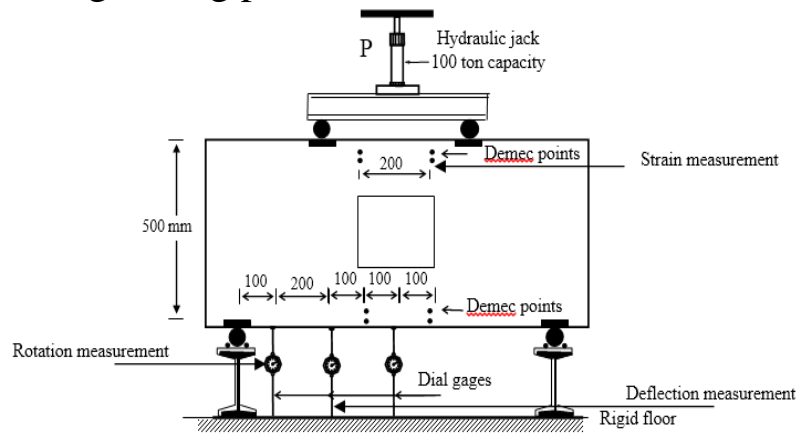

Fig. 6. Test setup and instrumentation

\section{ANALYSIS AND DISCUSSION OF THE TEST RESULTS}

Beams in the two groups were tested under incremental load up to failure. The results were analyzed and compared in different stages of loadings. The load-deflection curves and loadrotation curves were plotted; the first cracking and failure loads were recorded. The crack propagation, crack patterns (number of cracks, type of cracks) were marked and classified after each load increment. Finally modes of failure are numbered and classified photographed.

\section{Load Deflection behavior}

Shear strength in reinforced concrete conventional beams, $V_{n}$ in most reinforced concrete design codes (SBC 304 (2007), ACI318-08, Euro code 2 (2004)) is assumed to be the summation of contributions of concrete and stirrups as follows,

$$
V_{n}=V_{c}+V_{s}
$$

where, $V_{c}$, is the concrete contribution usually expressed as a function of key variables, (ACI426, 1987; ACI-445, 1998):

$$
V c=f\left(\rho, f_{c}, \frac{a_{v}}{d}, d\right)
$$

The stirrup contribution to shear strength, $V_{s}$, is affected by the longitudinal spacing of stirrups, $s$, legs area, $A_{v}$, yield strength, $f_{y v}$, and orientation and expressed as

$V s=\frac{A_{v} f y_{v d}}{S}$

Figure 7 and 8 represent the load deflection behavior of all RC tested beams. Figure 7 compares the load deflection curves at midspan for all tested beams. Figure 7 shows that both of the cracking and ultimate failure loads for beam BOC1 were slightly decreased due to the presence of opening. At the ultimate failure load of control beam BOC1, deflections were increased by about $1.8 \%$ more than the control beam without opening BC2. It is noticed that, the presence of opening in the center of the deep beam has small effect on the load behavior because the shear stresses dominate the failure behavior. Also it is noticed that ultimate failure load for beam BC2 were increased due to the 
higher percentage of reinforcement, this beam has a reinforcement ratio of $1.68 \%$ and the ultimate load recorded equal to $600 \mathrm{KN}$, On the other hand beams $\mathrm{BC} 1$ and $\mathrm{BOC} 2$ have a reinforcement ratio of $0.47 \%$, the ultimate load recorded equal to $450 \mathrm{KN}$. The ultimate load for beams $\mathrm{BC} 1$ and $\mathrm{BOC} 2$ was less than the ultimate load for beam BC2 by $150 \mathrm{KN}$. At the ultimate failure load of beam BOC2, deflections were increased by about $13.6 \%$ more than the control beam without opening $\mathrm{BC} 1$. It is noticed that, the presence of opening in the center of the deep beam has small effect on the load behavior because the shear stresses dominate the failure behaviour of the beam.

\section{Maximum Deflection}

Maximum deflections at mid-span for all tested beams were recorded and compared as shown in Fig. 8. It is noticed that for control beams $\mathrm{BC} 1$ and $\mathrm{BC} 2$, the beam $\mathrm{BC} 1$ has a maximum value of deflection recorded about the beam $\mathrm{BC} 2$ at the same load level this difference ranges between $20 \%$ to $40 \%$, So it is noticed that the beam which has a higher percentage of reinforcement ratio recorded minimum values of deflection. Also it is noticed that for beams with openings $\mathrm{BOC} 1, \mathrm{BOC} 2$, and $\mathrm{BOC} 3$ the beam $\mathrm{BOC} 2$ which has a reinforcement ratio of $0.47 \%$ recorded the maximum value of deflection compared with the beam BOC3 which has a reinforcement ratio of $0.94 \%$ and the beam BOC1 which has a reinforcement ratio of $1.68 \%$.

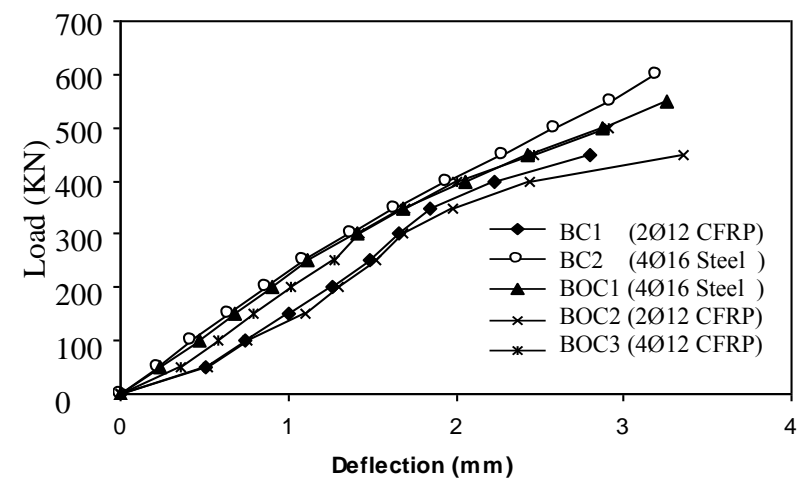

Fig. 7. Load Deflection curves at mid span for all tested beams

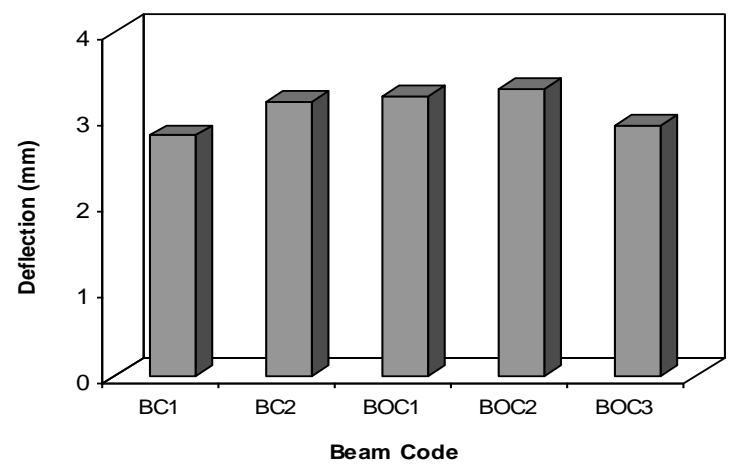

Fig. 8. Maximum deflection of all tested beams

\section{Load-Rotation behavior}

Figure 9 shows the load rotation curves at end support for all reinforced concrete deep tested beams. It is noticed that the beams which have a higher percentage of reinforcement ratio recorded maximum values of rotations $\mathrm{BC} 2$ and $\mathrm{BOC} 1$.

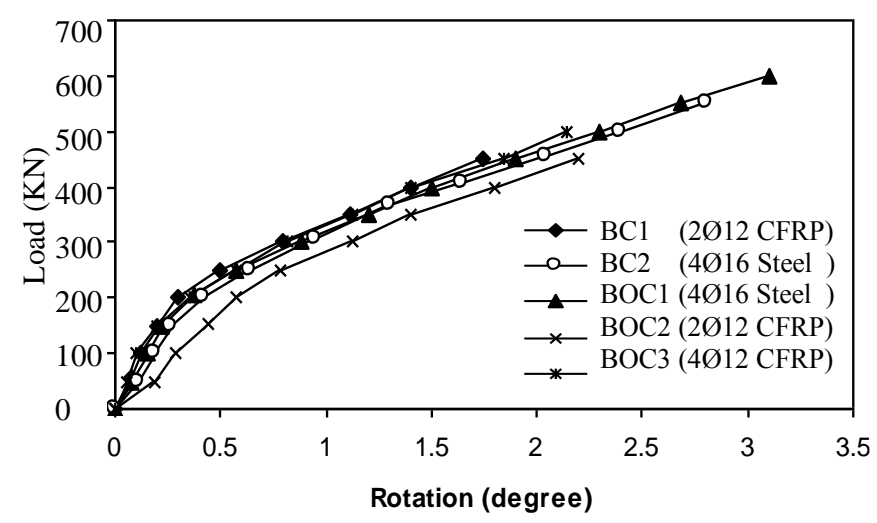

Fig. 9. Load Rotation curves at end support of all tested beams

\section{Maximum Rotation}

Maximum rotation at end support for tested $\mathrm{RC}$ deep beams are recorded and compared as shown in Figs. 9 and 10 and maximum values for the control beams was recorded for beam $\mathrm{BC} 2$ where the maximum rotation value for deep beam with opening was recorded for beam BOC1. 


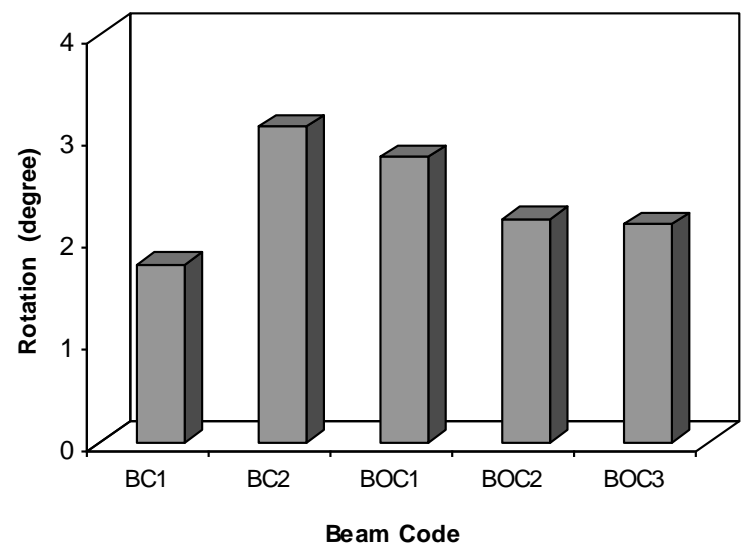

Fig. 10. Maximum rotation of all tested beams

\section{Cracking and Ultimate Loads}

The cracking and ultimate failure loads were recorded for all reinforced concrete deep tested beams as shown in Fig. 11 and 12. Figure 13 compares both cracking and failure loads for all tested beams. The ultimate load of the control beam $\mathrm{BC} 2$ was increased by about $9 \%$ than the ultimate load for control beam BOC1. The ultimate load for the control beam $\mathrm{BC} 1$ was the same as beam BOC2. The ultimate load for BOC 3 was increased by about $11 \%$ than the ultimate load of control beam BC1. It is noticed that the beam which has a higher percentage of reinforcement ratio recorded the maximum values of cracking and ultimate failure loads BC2. The tensile stress in the FRP reinforcement is calculated using Eq. 4 which is adopted from the ACI Committee 440 (ACI 440-06) design recommendations for the design of FRP-reinforced concrete when failure is governed by concrete crushing [9].

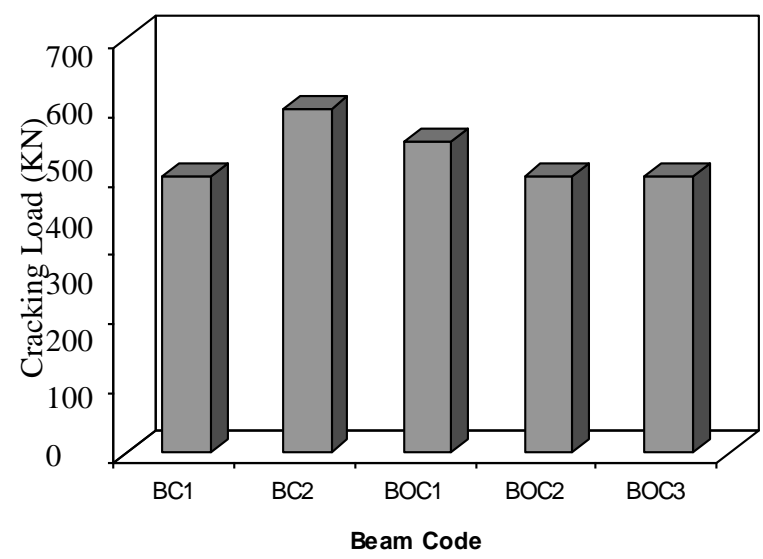

Fig. 11. cracking load of all tested beams
$\left.f_{f}=\left(\sqrt{\frac{\left(E_{f} \varepsilon_{c u}\right)^{2}}{4}}+\frac{0.85 \beta_{1} f^{\prime}{ }^{\prime}}{\rho_{f}} E_{f} \varepsilon_{c u}-0.5 E_{f} \varepsilon_{c u}\right) \leq f_{f u}\right)$

where $f_{f}$ is the tensile stress in the FRP flexural reinforcement, $E_{f}$ is the modulus of elasticity of the FRP reinforcement, $\varepsilon_{c u}$ is the ultimate strain in concrete, $\beta_{1}$ is a factor to reduce the concrete compressive strength, $\rho_{f}$ is the FRP reinforcement ratio, and $f_{f u}$ is the design tensile strength of the FRP reinforcement [9].

\section{Serviceability of SCC deep beams}

In the present work both deflections and rotations are studied for serviceability of deep beams, ductility of RC beam is defined as the ratio between the maximum deflection due to the ultimate load and the maximum deflection at the first cracking load. Energy absorption is defined as the area under the load-deflection curve at failure.

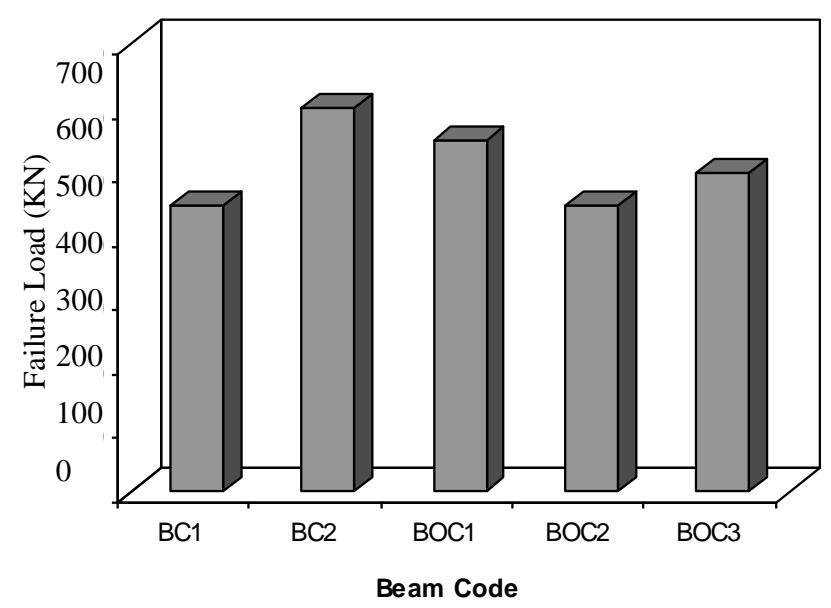

Fig. 12. Failure load of all tested beams

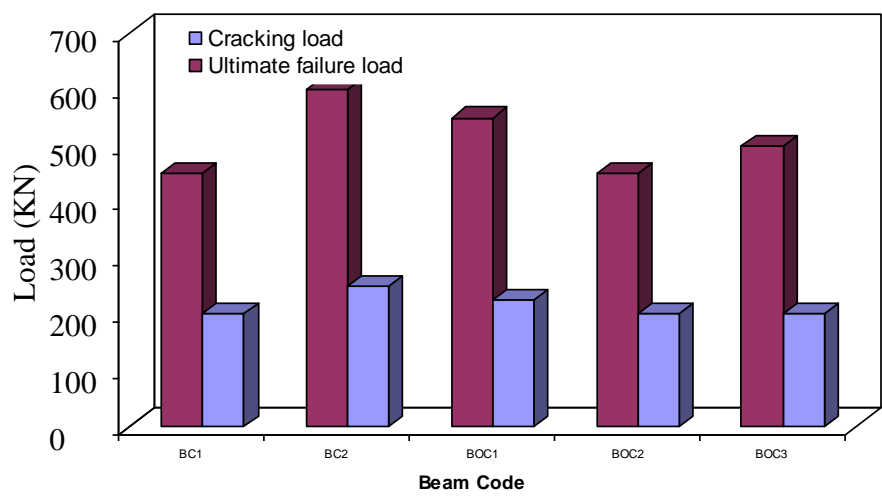

Fig.13. Cracking and ultimate failure loads for tested beams

Table 4 gives the test results for the ductility and the energy absorption for different self compacted reinforced concrete beams. In 
general, deflections of RC deep beams are small compared with shallow beams. As beam section height increases the stiffness of beam increases leading to brittle failure. Fig. 7 shows load deflection variation of studied RC deep beams. For all tested RC deep beams the load deflection curve is almost linear till ultimate strength failure. This shows that shear deformation is predominant behavior leading to brittle failure. The brittle failure reduces the strength of structural elements below the flexural capacity and considerably reduces the ductility of the elements. The area under load deflection curve represents the energy absorbed by structural elements during failure. For performance assessment of tested self compacted deep beams, the absorbed energy is calculated using the following equation:

$$
A=\frac{\left(P_{i}+P_{i+1}\right) *\left(\Delta_{i+1}-\Delta_{i}\right)}{2}
$$

where $A$ symbolizes the area under loaddeflection curve, $p_{i}$ represents the applied load and $\Delta_{i}$ indicates the measured deflection at mid span of beam at increment I of loading.

\section{Failure in $B$ and $D$ regions of SCC deep beams}

Based on the structural behavior the failure modes of $\mathrm{RC}$ deep beams can be classified into two regions $\mathrm{B}$ and $\mathrm{D}$. The $\mathrm{B}$ region follows Bernoulli theory in which the strain distribution is linear. In D region or Discontinuity region the strain distribution is non linear. D-regions include the area where concentrated load is applied or abrupt change in geometry occurs. According to St. Venant's principle the Dregion is equal to one section depth on either side of discontinuity [11-14]. Fig. 14 and 15 show the failure pattern of self compacted deep beams under study. As per St. Venant's principle, the whole beam is under $\mathrm{D}$ region. The $\mathrm{D}$ region experiences local failure at support and load point areas. Flexural failure is observed in pure bending zone. At compression strut trajectory the failure is pure shear by diagonal cracking. The area between compression strut and mid-span contains combined flexural and shear failure. Failure due to compression is observed at extreme compression fibre of mid-span as shown in figure 14 and 15 respectively.

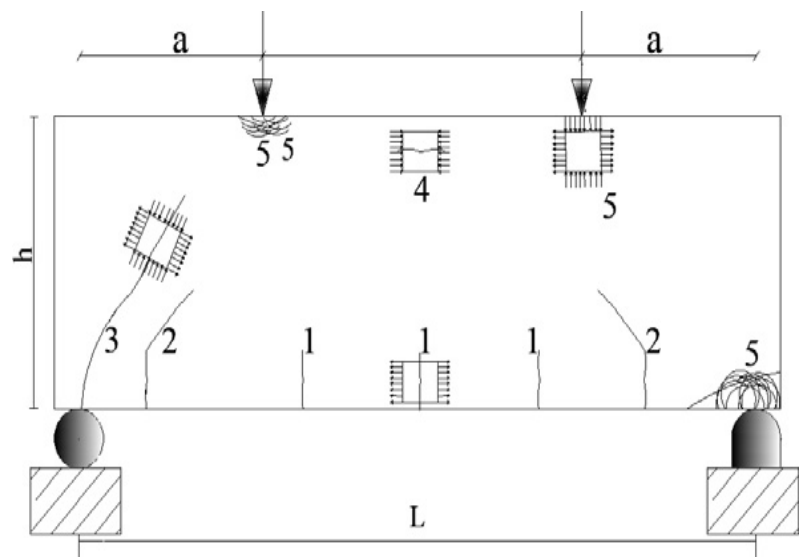

Fig. 14. Typical crack pattern of deep beams with four points loading [11].

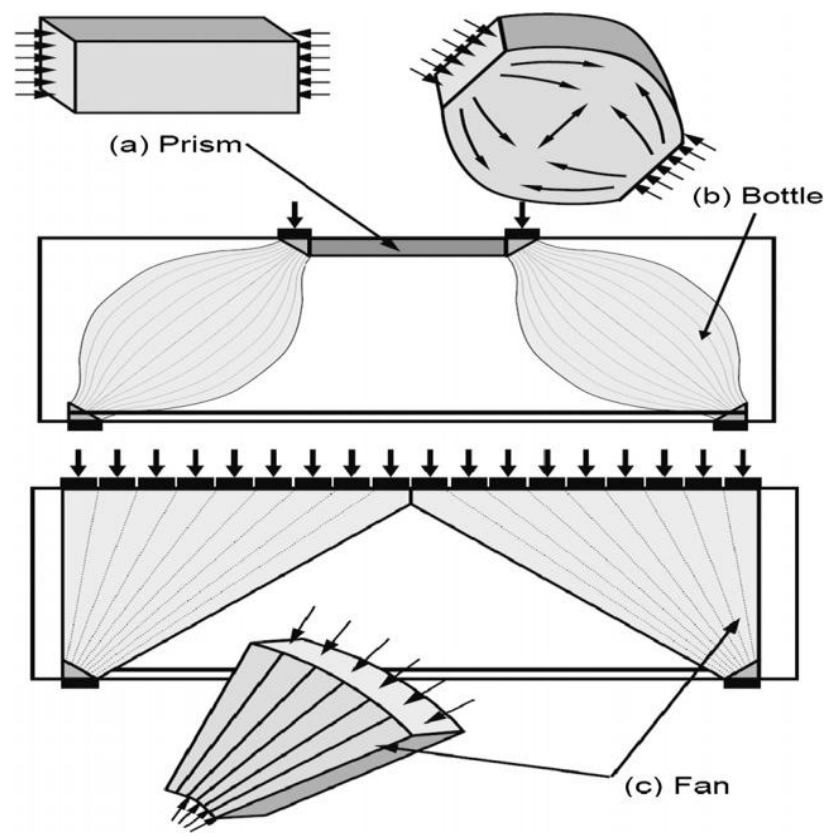

Fig. 15. Common types of strut 14 (a) prism, (b) bottle and (c) fan for deep beams under four points loading [12].

Table 4: Results of cracking, ultimate loads, ratio of first bending, maximum deflection, reinforcement ratio, ductility and energy absorption of reinforced concrete deep beams. 


\begin{tabular}{|c|c|c|c|c|c|c|c|c|}
\hline Group & Specimen & $\begin{array}{c}\text { Cracking } \\
\text { Load, } \\
\text { PCr } \\
(\mathrm{KN})\end{array}$ & \begin{tabular}{|c} 
Ultimate \\
Load, Pu \\
(KN)
\end{tabular} & $\begin{array}{c}\text { Ratio of } \\
\text { first crack } \\
\text { load to } \\
\text { ultimate } \\
\text { load }\end{array}$ & \begin{tabular}{|c} 
Max. \\
Deflectio \\
(mm)
\end{tabular} & $\begin{array}{c}\text { Ratio of } \\
\text { reinforcem } \\
\text { nt } \\
\%\end{array}$ & $\begin{array}{c}\text { Ductility } \\
\text { Ratio }\end{array}$ & $\begin{array}{c}\text { Energy } \\
\text { Absorptio } \\
\mathrm{n} \\
\text { (mm . ton) }\end{array}$ \\
\hline \multirow{2}{*}{ Group A } & $\mathrm{BC} 1$ & 200 & 450 & 0.444 & 2.80 & $0.47 \%$ & 2.22 & 63.0 \\
\hline & $\mathrm{BC} 2$ & 250 & 600 & 0.417 & 3.20 & $1.68 \%$ & 2.93 & 96.0 \\
\hline \multirow{3}{*}{$\begin{array}{c}\text { Group } \\
\text { B }\end{array}$} & BOC1 & 225 & 550 & 0.409 & 3.26 & $1.68 \%$ & 3.22 & 89.6 \\
\hline & BOC2 & 200 & 450 & 0.444 & 3.35 & $0.47 \%$ & 2.57 & 75.4 \\
\hline & BOC3 & 200 & 500 & 0.400 & 2.91 & $0.94 \%$ & 2.85 & 72.8 \\
\hline
\end{tabular}

Fracture Behavior, Failure Analysis, Cracking Patterns and Modes of Failure of self compacted concrete deep beams

Figures 16 through 20 show the crack patterns at different loading stages for all tested RC deep beams. The mode of failure for all beams was recorded discussed and classified. Figure 16 shows the crack pattern of the control beam BC1. Cracks starts at load $200 \mathrm{KN}$ from the lower level near the center of the beam at the tension side and developed upward. For further loading, cracks starts and increased in the region near supports and directed towards the loading position till failure forming a shear failure. Figure 17 shows the crack pattern of the control beam BC2. Cracks start at load $250 \mathrm{KN}$ and developed with the same procedure as the previous beam BC1. Figure 18 shows the crack pattern of beam BOC1. Cracks start at $225 \mathrm{KN}$ and developed with the same procedure as the previous beam BC2. Figure 19 and figure 20 shows the crack pattern of beams BOC2 and BOC3. Cracks start at $200 \mathrm{KN}$ and developed with the same procedure as the previous beam $\mathrm{BC} 1$. It is concluded from the above discussion that the presence of central opening has small effect in case of shear failure.

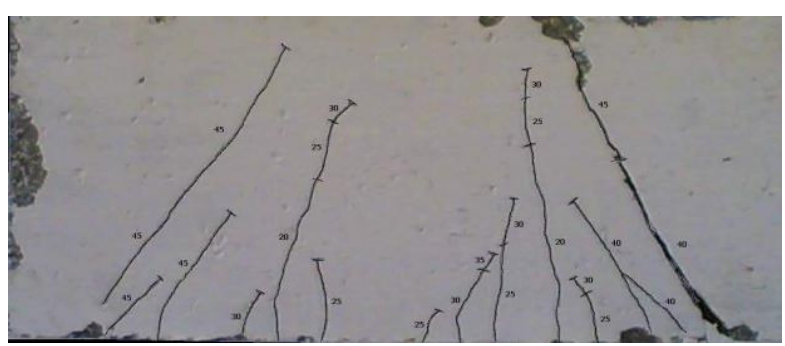

Fig. 16. Crack pattern and mode of failure of the control beam BC1(2Ø12 CFRP) (P $P_{c r}=$ $200 \mathrm{KN}$ and $P_{\mathrm{ult}}=450 \mathrm{KN}$ )

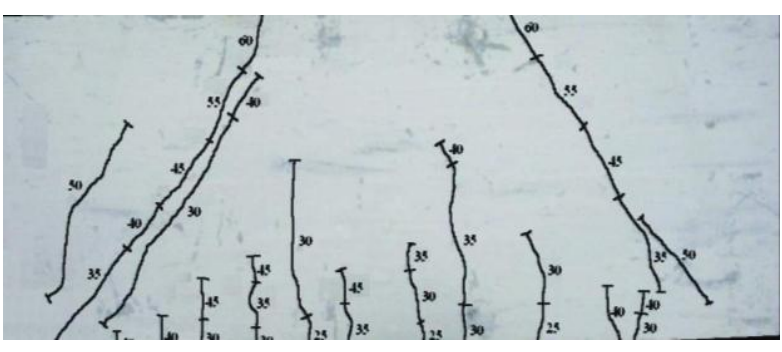

Fig. 17. Crack pattern and mode of failure of the control beam BC2 (4Ø16 Steel $)\left(P_{\text {cr }}=250 \mathrm{KN}\right.$ and $\left.P_{\text {ult }}=600 \mathrm{KN}\right)$

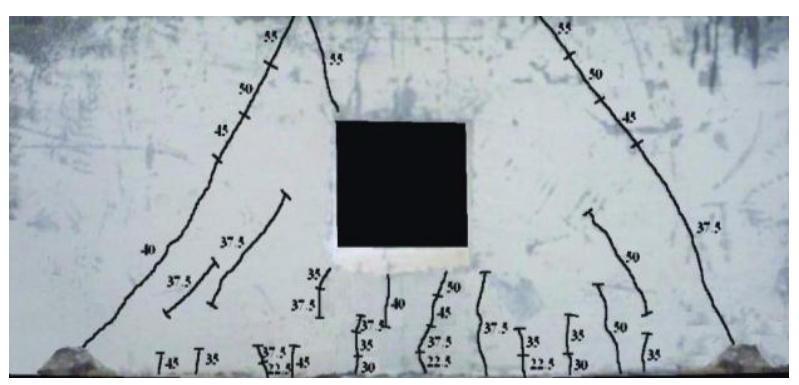

Fig. 18. Crack pattern and mode of failure of beam BOC1 (4Ø16 Steel) ( $P_{\mathrm{cr}}=$ $225 \mathrm{KN}$ and $P_{\text {ult }}=550 \mathrm{KN}$ )

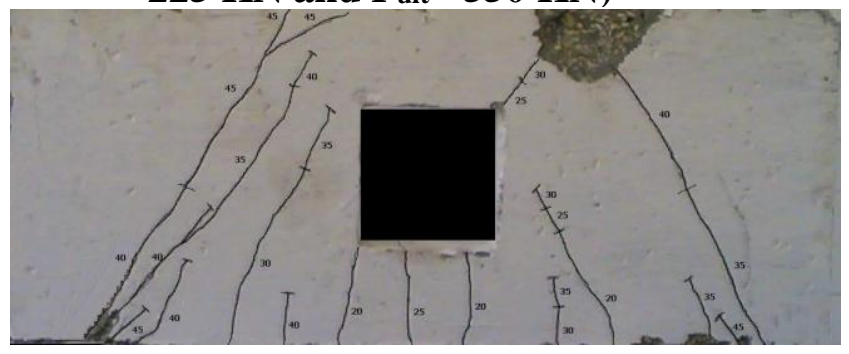

Fig. 19. Crack pattern and mode of failure of beam BOC2 (2Ø12 CFRP) $\left(P_{\text {cr }}=200 \mathrm{KN}\right.$ and $P_{\text {ult }}=450 \mathrm{KN}$ )

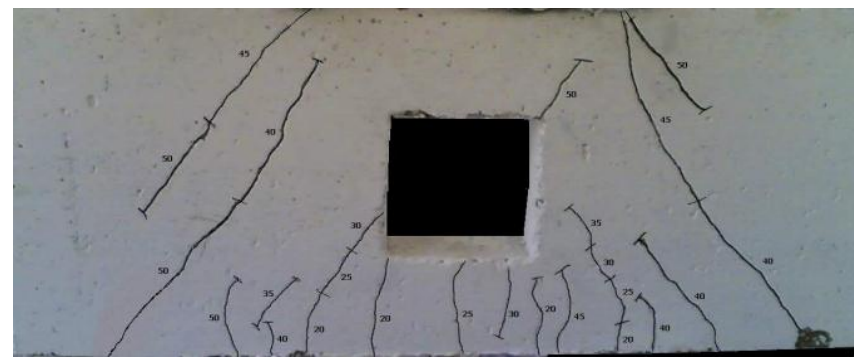

Fig. 20. Crack pattern and mode of failure of beam BOC3 (4Ø12 CFRP) $\left(P_{c r}=200 \mathrm{KN}\right.$ and $P_{\text {ult }}=500 \mathrm{KN}$ ) 


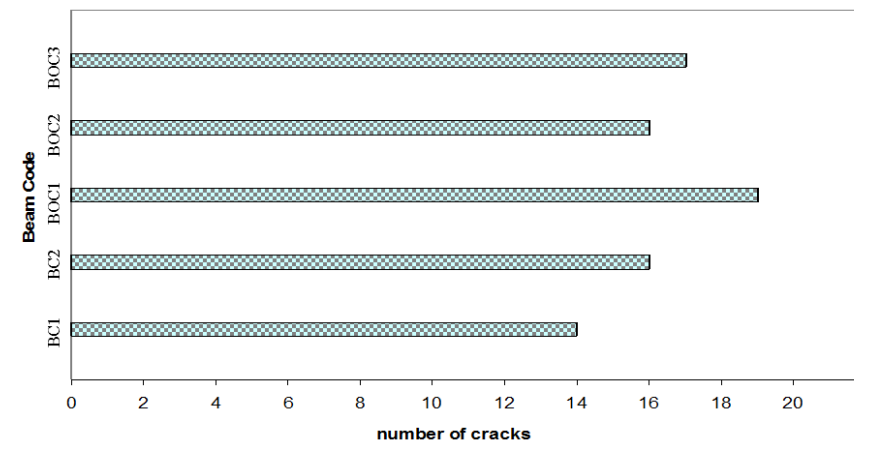

Fig. 21. The total number of cracks in the tested self compacted deep beams

Figure 21 represents the total number of cracks recorded for each $\mathrm{RC}$ deep beam. It is clear from figure that deep beam BOC1 has a high number of cracks owing to presence of all types of cracking and modes of failure.

\section{Flexural failure in SCC deep beams}

Figure 22 shows the number of cracks at mid span for all RC deep beams after failure. These are pure flexural cracks and are labeled as type (1). The cracks appear when the tension stress exceeds tensile strength of concrete. The cracks are vertical due to the effect of horizontal tension stress in pure bending zone. The appearance of these cracks is due to inherent shortage of concrete in tension. From Figure 16 it is found that the number of flexural cracks for beam $\mathrm{BC} 1$ equal 6 , these cracks occurred at 200, 250, and $300 \mathrm{KN}$ of load levels. From Figure 17 it is showed that the number of flexural cracks for beam $\mathrm{BC} 2$ equal 8 , these cracks occurred at 250,300,350, and $400 \mathrm{KN}$ load levels. From Figure 18 it is noted that the number of flexural cracks for beam BOC1 equal 9 , these cracks occurred at 225, 300, 350, $375,400,450$, and $500 \mathrm{KN}$ of load levels. From Figure 19 it is observed that the number of flexural cracks for beam BOC2 equal 5, these cracks occurred at 200, 250, 300, 350, and 400 $\mathrm{KN}$ of load levels. From Figure 20 it is found that the number of flexural cracks for beam BOC 3 equal 6 , these cracks occurred at 200 , $250,300,350$, and $400 \mathrm{KN}$ of load levels.

\section{Shear failure in SCC deep beams}

Figure 23 shows the number of cracks due to shear failure type (2) in tested RC self compacted deep beams. In deep beams, significant part of load is transferred to support directly through compression struts formed between load and support points.

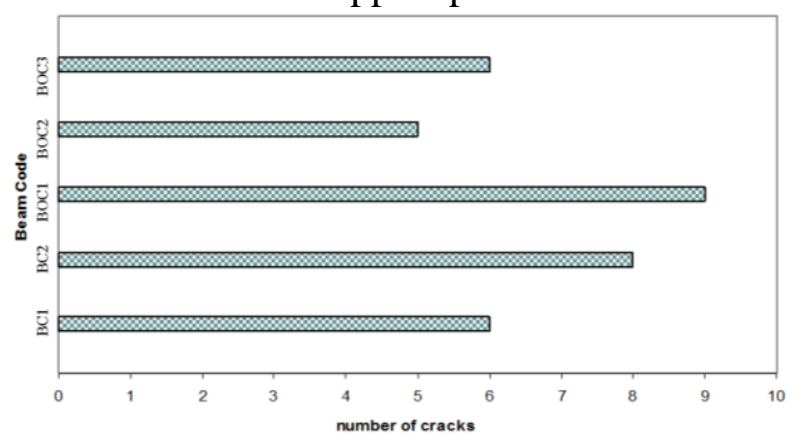

Fig. 22. The number of cracks due to flexural failure type (1) in tested self compacted deep beams

This mechanism of transferring load leads to the type of failure that is most common in deep beams. The deep beams fail by widening of diagonal shear cracks and crushing of concrete. From Figure 16 it is found that the number of shear cracks for beam $\mathrm{BC} 1$ equal 4 , these cracks occurred at 400 , and $450 \mathrm{KN}$ of load levels. From Figure 17 it is observed that the number of shear cracks for beam $\mathrm{BC} 2$ equal 5 , these cracks occurred at 400, 450, 500, 550, and 600 $\mathrm{KN}$ load levels. From Figure 18 it is noted that the number of shear cracks for beam BOC1 equal 6 , these cracks occurred at $375,400,450$, 500 , and $550 \mathrm{KN}$ of load levels. From Figure 19 it is showed that the number of shear cracks for beam BOC2 equal 5, these cracks occurred at 350,400 , and $450 \mathrm{KN}$ of load levels. From Figure 20 it is found that the number of shear cracks for beam BOC3 equal 5, these cracks occurred at 400, 450, and $500 \mathrm{KN}$ of load levels.

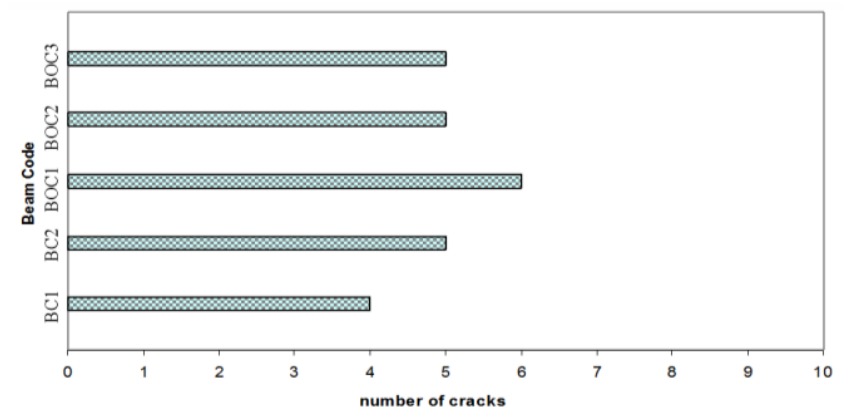

Fig. 23. The number of cracks due to shear failure type (2) in tested self compacted deep beams 


\section{Combined flexural shear failure in SCC deep beams}

Type (3) cracks are the combined flexural and shear cracks. It can be observed the number of flexural and shear cracks from figure 24 that upon increasing the load, inclined cracks appear at the end of vertical cracks. These cracks are directed towards the load points. These cracks seldom appear as failure crack at ultimate load. From Figure 16 it is found that the number of flexural shear cracks for beam BC1 equal 4, these cracks occurred at 300, 400, and $450 \mathrm{KN}$ of load levels. From Figure 17 it is found that the number of flexural shear cracks for beam BC2 equal 3, these cracks occurred at 300, 350 and $400 \mathrm{KN}$ load levels. From Figure 18 it is found that the number of flexural shear cracks for beam BOC1 equal 4, these cracks occurred at $350,375,450$, and $500 \mathrm{KN}$ of load levels. From Figure 19 it is found that the number of flexural shear cracks for beam BOC2 equal 6 , these cracks occurred at 300,350, and $400 \mathrm{KN}$ of load levels. From Figure 20 it is found that the number of flexural shear cracks for beam BOC3 equal 6 , these cracks occurred at 350 , 400 , and $500 \mathrm{KN}$ of load levels.

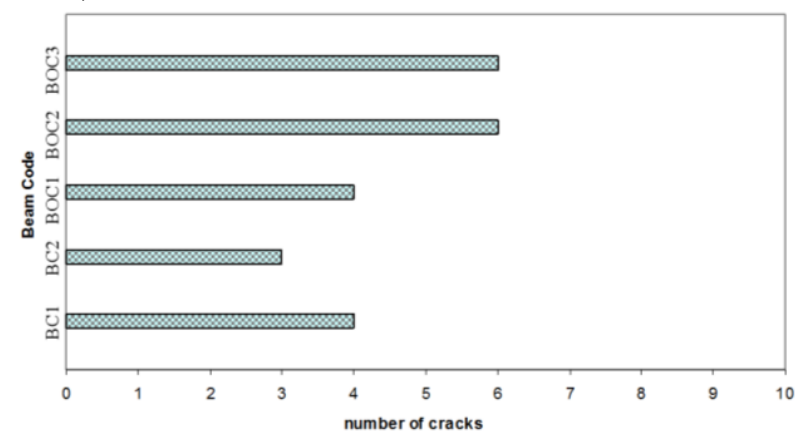

Fig. 24. The number of cracks due to combined flexural shear failure type (3) in tested self compacted deep beams

\section{Local failure of SCC deep beams}

Figures 16, 18, 19, and 20 show local failure at support and loading points. This failure is denoted as type (4). It is due to high compressive stress occurring in the area around load and support. From Figure 16 it is found that the number of local crack for beam BC1 equal 4 cracks. From Figure 17 there is no local failure crack for beam BC2. From Figure 18 it is found that the number of local crack for beam BOC1 equal 2 cracks. From figure 19 it is found that the number of local crack for beam BOC2 equal 3 cracks. From Figure 20 it is found that the number of local crack for beam BOC 3 equal 1 crack.

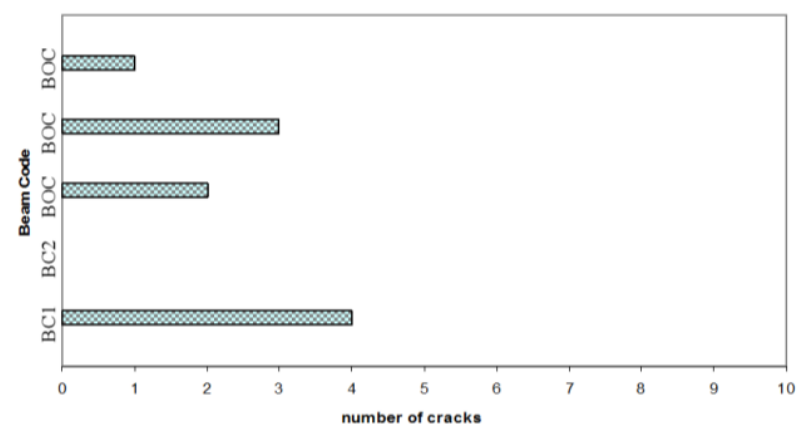

Fig. 25. The number of cracks due to local failure type (4) in tested self compacted deep beams

\section{CONCLUSIONS}

Based on the test results presented in this study, which aimed to investigate the fracture behavior and failure analysis of SCC deep beams reinforced with FRP bars, the following conclusions can be drawn:

1. Using FRP bars as main reinforcement improves the ductility behavior of beam elements under static loads.

2. In elastic zone of deep beam behavior, using SCC results in a reduction in rotation angles at supports, and deflection of deep beam element when FRP bars is used as main reinforcement.

3. Adequate design for deep beam elements, reinforced with FRP bars, under shear forces is essential because the shear strength of such elements is less than those reinforced with confentional steel bars.

4. Central openings with proper dimensions in self compacted deep beams have small effects wherever shear stresses dominant the failure behaviour.

5. Fracture behaviour and failure analysis of SCC Deep beams can be summarized as flexural failure, shear failure, combined flexural shear failure and finally local failure. 


\section{REFERENCES}

[1] Selvam V.K.M, "Shear strength of reinforced concrete deep beams", Building and environment, Vol. 11, pp. 211-214, Pregman press 1976.

[2] Soliman, S.M.H., "Behavior and Analysis of Reinforced Concrete Deep Beams", M.Sc. thesis, Menoufiya University, 2003.

[3] Nanni, A., ,"FRP Reinforcement for Bridge Structures", proceedings, Structural Engineering Conference, The University of Kansas, Lawrence, KS, 16 March, 2000.

[4] Aguilar, G., Matamoros, A.B., Montensinos, G.J.P., Ramirez, J.A., and Wight, J.K., , "Experimental Evaluation of Design Procedures for Shear Strength of Deep Reinforced Concrete Beams", ACI Structural Journal, V.99, No.4, JulyAugust, pp. 539-548, 2002.

[5] Russo, G., Venir, R., and Pauletta, M.,"Reinforced Concrete Deep BeamsShear Strength Model and Design Formula", ACI Structural Journal, V.102, No.3, May-June, pp. 429-437, 2005.

[6] Oh, J.K., and Shin, S.W., "Shear Strength of Reinforced High-Strength Concrete Deep Beams", ACI Structural Journal, Vol.98, No.2, March-April, pp.164-173, 2001.

[7] Yousef, A.M., "Shear Strength Prediction of High-Strength Fiber Reinforced Concrete Deep Beams", Tenth International Colloquium on Structural and Geotechnical Engineering, Ain Shams University, Cairo, Egypt, April, 2003.

[8] MBT technical datasheet, E-mail: enquire.egypt@ degussa.com, Website: www.mbt-egypt.com

[9] ACI 440-06, Fiber-Reinforced Polymer (FRP) Reinforcement for Concrete Structures, 2006.

[10] ACI 318-building code, 2014.

[11] Vang, K.H., Chung, H.S., Lee, Et., Eun, H.C. " Shear Characteristics of high strength concrete deep beams without shear reinforcements", Engineering structures 25, 1343-1352, 2003.

[12] Nehdi, M., Omeman, Z. El-Chabib, H., “ Optimal efficiency factor in strut-and-tie model for FRP-reinforced concrete short beams", Materials and structures, 41:17131727, 2008.

[13] Aswin M, Basher S. M, Liew M. S, and Zahir I.S., "Shear failure of RC dapped end beams", Advances in Materials science and engineering, Volume 2015, article ID 309135, 11 pages, http://dx.doi.org//0.1155/2015/309135.

[14] Attarde, P. M and Barbat, D. K, "behaviour and strength of RC Deep beams using high performance concrete-A letrature review", International Journal of Modern Trends in Engineering and Reseach, Volume 02, Issue 02, February 2015. 